\title{
A CORRENTE SUBSTANCIALISTA: PROSPERIDADE E EXPANSÃO JURISDICIONAL FRENTE AO ESTADO DEMOCRÁTICO DE DIREITO"
}

\section{The substantialist current: prosperity and jurisdictional expansion front Democratic Rule of Law}

\author{
Vinícius Almada Mozetic ${ }^{* * *}$ \\ Paulo Junior Trindade dos Santos ${ }^{* * * *}$
}

\section{Resumo}

A corrente substancialista demonstra-se próspera e em ampla expansão Jurisdicional frente ao Estado Democrático de Direito, no

Recebido: 27 de julio de 2016 - Aprobado: 12 de mayo de 2017

* Artículo inédito.

Para citar el artículo: TRINDADE DOS SANTOS, Paulo Junior y ALMADA MOZETIC, Vinícius. A corrente substancialista: prosperidade e expansão jurisdicional frente ao Estado democrático de direito. Revista del Instituto Colombiano de Derecho Procesal. No. 45, Junio - Diciembre. 2017. Bogotá: Instituto Colombiano de Derecho Procesal, pp. 77-107.

** Doutorando (2014-01 em andamento) pela Universidade do Vale do Rio dos Sinos UNISINOS; Mestre (2009-2011) pela Universidade de Santa Cruz do Sul - UNISC- Direitos Sociais e Políticas Públicas; Professor e Pesquisador do Programa de Pós-Graduação em Direito da Universidade do Oeste de Santa Catarina - UNOESC; Coordenador do curso de Direito da Universidade do Oeste de Santa Catarina - UNOESC. Advogado.

**: Doutorando (2014-01 em andamento) com Bolsa pela Coordenação de Aperfeiçoamento de Pessoal de Nível Superior (CAPES); e Mestre (2011-2013) com Bolsa pelo Conselho Nacional de Desenvolvimento Científico e Tecnológico (CNPq), ambos em Direito pela Universidade do Vale do Rio dos Sinos (UNISINOS). Compõe o Grupo de Estudos: O processo civil contemporâneo: do Estado Liberal ao Estado Democrático de Direito. 
qual o juiz-tribunal, por meio da interpretação construtiva/criadora de direito, passa a decidir de forma mais adequada utilizando-se da Hermenêutica Jurídica de cunho Filosófico fazendo com que suas decisões, sim decisões políticas venham a interferir profundamente: tanto no Poder Legiferante quanto no Poder Executivo, que tem por consequência efeitos irradiados diretamente na Sociedade.

Palavras-chave: Substancialismo; Expansão Jurisdicional; Estado Democrático de Direito.

\begin{abstract}
The current substantialist shows up thriving and broad expansion Jurisdictional from the Democratic Rule of Law, in which the judge-court, through constructive interpretation / creator of law, shall decide the most appropriate way is using the Legal Hermeneutics of Philosophical making their decisions, rather political decisions may interfere deeply: both as legislative power in the executive branch, which has the effect irradiated directly in the Company.
\end{abstract}

keywords: Substantialism; Jurisdictional expansion; Democratic State.

\title{
Introdução
}

A corrente substancialista é um assunto que interessa à comunidade científica e à sociedade como um todo. Com efeito, a noção de Estado Democrático de Direito está indissociavelmente ligada à realização dos direitos fundamentais sua eficácia.

O presente trabalho posiciona-se de maneira a entender que o Poder Judiciário não deve assumir uma condição passiva diante da sociedade, fazendo assim introjetar a política no Direito ${ }^{1}$, o que tem conduzido a efetuar indevidas abordagens de discussão ${ }^{2}$. Também se justifica a Teoria Política ${ }^{3}$ do Direito em

$1 \quad$ BODNAR, Zenildo; STAFFEN, Márcio Ricardo. Juizados especiais e ativismo judicial à luz de Luis Alberto Warat. In: Sequência (Florianópolis) No.64 Florianópolis jul. 2012.

2 PICÓ i JUNOY. El Derecho Procesal entre el Garantismo y el eficácia: Un debate mal planteado. In: AROCA, Juan Montero (Coord.). Proceso Civil e Ideología. Un prefacio, una sentencia, dos cartas y quince ensayos. Valencia: Tirant to Blanch, 2006, p. 111.

3 El triple imperativo político libertad-igualdad-fraternidad debe modularse, ya que la libertad sola destruye la igualdad, la igualdad impuesta destruye la libertad, y la fraternidad, que no se puede imponer, depende conjuntamente de un sistema de reformas políticas (entre ellas, las casas de solidaridad, el servicio cívico de solidaridad), reformas educativas y reformas individuales (entre ellas, la de vida y la ética). Así pues, la reducción progresiva de las desigualdades debe efectuarse, simultáneamente, medíante 
algumas questões, sendo a primeira que se reporta tanto aos fundamentos do Direito: circunstâncias nas quais preposições jurídicas especificam e devem ser aceitas como bem fundadas ou verdadeiras; e a segunda quanto à força do direito: o relativo poder que em toda e qualquer verdadeira preposição jurídica de justificar a coerção em vários tipos de circunstâncias excepcionais. Essas duas questões devem se apoiar mutuamente. Pois uma teoria sobre os fundamentos que, em si mesma, não assume nenhuma posição relativa à utilidade da força do direito, deve ainda assim ser política, num sentido mais geral e difuso ${ }^{4}$.

Tem como finalidade o substancialismo que procura a melhor luz em meio às ruínas da dogmática jurídica positivista apregoada no formalismo do Direito, pois com este eixo, tanto por meio do Processo Legislativo (procedimento), quanto por meio do Processo Judiciário (procedimento) ambos então, legitimados para com esta atividade de criação do Direito ${ }^{5}$.

una política planetaria (política de la humanidad, política de civilización), políticas nacionales que reduzcan las diferencias de niveles de vida y regeneren las solidaridades, combatiendo la corrupción, y mediante reformas de vida y reformas éticas, que favorezcan la comprensión de las miserias y las desdichas ajenas. Esta política comporta una dimensión monetaria, pero es, también, multidimensional, y forma parte de las vías múltiples que proponemos abrir simultáneamente. (MORIN, Edgar. La Vía. Para el futuro de la humanidad. $1^{\text {a }}$ Ed. Barcelona: Paidos, 2011, p. 135.

4 DWORKIN, Ronald. O Império do Direito. $1^{\text {a }}$ ed. São Paulo: Martins Fontes, 1999, pp. 136-138.

5 Essas representam, ao mesmo tempo, as naturais limitações - sobre as quais voltaremos - mas, também, única força do processo jurisdicional. Ninguém, suponho, veria uma perversão do processo legislativo no fato de que os legisladores estejam co-envoltos e empenhados, ainda que com o espírito de parte ou de partido, nas matérias que regulam; ou no fato de que esses consideram-se os representantes de pessoas, grupos, categorias, classes, nos qual se instruem para secundar os interesses no processo de formação as leis; ou, ainda, no fato de que esses dão a mãos à atividade legislativa d própria iniciativa sem atender a pedidos dos sujeitos ou grupos interessados; ou, por fim, no fato de que embora possam existir tais pedidos, estes não limitam o ato legislativo aos termos da própria petição. Nos limites de decência e honestidade políticas, esse modo de atitude do legislador é perfeitamente correto; mas seria, ao contrário, de todo intolerável se fosse assunto de uma Corte Judiciária. Na verdade, uma corte que se comportasse dessa maneira, simplesmente, cessaria de ser uma Corte de Justiça. Aquilo que distingue o processo jurisdicional daquele legislativo, e que faz com que a criação do Direito por obra dos Juízes permaneça bem distinta da legislação, não é, portanto, uma função abusiva de não criatividade mas, isto sim, uma particular modalidade daquele processo que se traduz na conexão d função judiciaria com cases and controversies, e na "virtude passiva", e "passividade" do Juiz quando a iniciar o processo nesses casos, e a imparcialidade processo do próprio Juiz, imparcialidade que há de traduzir-se num "processo justo" ou fair hearing de todas as partes. (CAPPELLETTI, Mauro. Processo, Ideologia e Sociedade. Vol. 1. Porto Alegre: Sergio Antonio Frabris Editor, 2008, pp. 17-18). 


\section{O Poder Judiciário como intérprete}

Estas são as circunstâncias que tornam indispensáveis conferir as possibilidades da construção de uma autêntica democracia quando o indivíduo toma o lugar do cidadão. A compatibilidade entre a democracia e individualismo é problema crucial que deve ser tratado quando se pretende um direito processual que supere o dogmatismo que permeia uma expressão de regime autoritário. É, em última análise, a expressão jurisdicional do pensamento único neoliberal. $\mathrm{O}$ acesso hermenêutico às realidades jurídicas contingentes, fica, consequentemente, vedado ao pensamento dogmático ${ }^{6}$.

Para Streck:

"É desse liame indissolúvel que exsurge aquilo que se pode denominar de plus normativo do Estado Democrático de Direito. Mais do que uma classificação de Estado ou de uma variante de sua evolução histórica, o Estado Democrático de Direito faz uma síntese das fases anteriores, agregando a construção das condições de possibilidades para suprir as lacunas das etapas anteriores, representadas pela necessidade do resgate das promessas da modernidade, tais como igualdade, justiça social e a garantia dos direitos humanos/fundamentais e sociais"? ${ }^{7}$

Nota-se que as questões processuais levantadas diante do julgamento político são bem complexas, em que as questões substantivas são tratadas como questões de princípios de moral política, refletindo diretamente na decisão não apenas de suas opiniões sobre a Justiça e a equidade, mas suas convicções de ordem superior sobre a possibilidade de acordo entre esses ideais quando competem entre $\mathrm{si}^{8}$.

Denota o Substancialismo que o Poder Judiciário através de suas decisões cria direito utilizando da interpretação criadora e construtiva que tem sido extraordinariamente eficaz, rompendo assim com o formalismo do Direito. Abre o Poder Judiciário novos espaços diante do ordenamento jurídico.

"Nesse eixo, aquilo que pode ser entendido à semelhança da vontade geral rousseauniana, uma vez bloqueado pelas circunstâncias próprias à sociabilidade e à vida política contemporânea, acaba encontrando expressão, pragmaticamente, em personagens e instituições cuja história particular se

6 SILVA, Ovídio A. Batista da. Processo e Ideologia: o paradigma Racionalista. 2. Ed. Rio de Janeiro: Editora Forense, 2006, p. 307.

7 STRECK, Lenio Luiz. Jurisdição constitucional e decisão jurídica. São Paulo: Editora Revista dos Tribunais, 2013, p. 150.

8 DWORKIN, Ronald. O Império do Direito. $1^{\text {a }}$ ed. São Paulo: Martins Fontes, 1999, p. 306. 
apresentaria como o resultado de conquistas da ideia do justo positivadas no direito e enraizadas na cultura política"”.

Impõe-se uma nova pragmática que se encontra obstaculizada pela legalidade, a qual o juiz deve introduzir por meio de sua sentença a Justiça, que se vê como a resistência contra as injustiças do Poder legiferante, tornando a atividade criadora do juiz, fonte que vem a acompanhar mais adequadamente as reivindicações sociais Nesse sentido, há que se falar, ultrapassando a rígida separação dos poderes pela divisão dos mesmos, que ganha assim uma nova redefinição aos seus contornos:

"Em síntese, a corrente substancialista entende que, mais do que equilibrar e harmonizar os demais Poderes, o Judiciário deveria assumir o papel de um intérprete que põe em evidência, inclusive contra maiorias eventuais, a vontade geral implícita no direito positivo, especialmente nos textos constitucionais, e nos princípios selecionados como de valor permanente na sua cultura de origem e no Ocidente. Coloca, pois, em xeque, o princípio da maioria, em favor da maioria fundante e constituinte da comunidade política”. ${ }^{10}$

É certo que razões pragmáticas sugerem uma separação entre o Poder Legislativo e o Judiciário, tão logo a configuração dogmática do direito e a cientifização da jurisprudência acarretam uma ampla profissionalização da prática de decisão judicial. ${ }^{11}$ A interpretação criativo-construtiva do Direito torna-se, desse modo, uma via para o escape do paradigma racional-dedutivo do Direito.

Notadamente, tanto o procedimento judiciário quanto o legislativo resultam em criação do direito, ambos são law-making process, divergindo somente a técnica do procedimento, ou estrutura de tais procedimentos de formação de direito, embora repetitivamente fale dos juízes-tribunais como "Órgãos exercentes do Poder Legislativo", que agem como legisladores, afirmando-se, assim, que os juízes "criam direito"12.

$9 \quad$ VIANNA, Luiz Werneck; CARVALHO, Maria Alice Resende de; MELO, Manuel Palácios Cunha; BURGOS, Marcelo Baumann. A judicialização da política e das relações sociais no Brasil. Rio de Janeiro: Renavan 1997, p. 38.

10 STRECK, Lenio Luiz. Jurisdição Constitucional e Hermenêutica - Uma nova crítica do direito. Porto Alegre: Livraria do Advogado, 2002, p. 141.

11 HABERMAS, Jürgen. Direito e Democracia: entre factividade e validade. Volume I. Tradução: Flávio Beno Siebeneichler. Rio de Janeiro: Tempo Brasileiro, 1997, p. 215.

12 CAPpelletti, Mauro. Juízes Legisladores? Tradução: Carlos Alberto Álvaro de Oliveira. Porto Alegre: Sérgio Antônio Fabris Editor, 1993, p. 74 
Neste sentido, não se pode esquecer que o substancialismo não abre mão do procedimentalismo ${ }^{13} \cdot{ }^{14}$ Ambos os procedimentos democráticos, tanto o legislativo quanto o judiciário, o têm como ponto de vista substancial. Portanto, não é diversa a "natureza" dos dois processos, o legislativo e o jurisdicional. Ambos constituem processos de criação do direito ${ }^{15}$.

13 Se as posturas procedimentalistas pretendem esgotar essa discussão a partir da garantia do processo democrático de formação das leis, isso, no entanto, não esgota a discussão da concreta normatividade, locus do sentido hermenêutico do direito. De fato, mais do que apostar na formulação democrática do direito, há que se fazer uma aposta paradigmática, isto e, acreditar na perspectiva pós-positivista do constitucionalismo contemporâneo e sua materialidade principiológica. A virtude soberana não se dá simplesmente na formulação legislativa e na "vontade geral". Fundamentalmente, ela será encontrada na Constituição, que estabeleceu uma ruptura com a discricionariedade política que sempre sustentou o positivismo. E tudo isso está ancorado no contramajoritarismo, que vai além do mero controle da aferição da correção dos procedimentos democráticos utilizados na feitura das leis. Também e na Constituição que encontraremos os mecanismos de controle da aferição substancial dos textos legislados e da aplicação destes textos (nunca esqueçamos: o substancialismo não abre mão do procedimentalismo). A igualdade, o devido processo legal, o sentido do republicanismo, a perspectiva de Estado Social, a obrigação de concretização dos direitos fundamentais-sociais, para citar apenas estes componentes paradigmáticos, são obrigações principiologicas de raiz, que vinculam a aplicatio. E os componentes a serem utilizados na discussão da aplicação do direito somente poderão exsurgir desse paradigma constitucional. Legislação democraticamente produzida - e valida - significa "sentido filtrado principiologicamente". O combate que aqui se trava - de cariz antidiscricionário - tem o objetivo de preservar esse grau acentuado de autonomia que o direito adquiriu com a fórmula das Constituições compromissórias (e dirigentes). (...) Mas uma questão deve ficar clara desde logo: as divergências entre as posturas substancialistas (que acoplam a noção de Estado o conteúdo material das Constituições que apontam para a mudança do status quo da sociedade, colocando grande ênfase no papel da justiça constitucional na efetivação dos direitos fundamentais-sociais) e procedimentalistas (calcadas na noção de democracia procedimental propugnada por Jurgen Habermas, mormente em seu Direito e democracia - entre faticidade e validade) não podem opô-las a ponto de se pensar, por exemplo, que o substancialismo não e pluralista ou que o procedimentalismo possa ser reduzido a uma perspectiva meramente "formalista". (STRECK, Lenio Luis. Verdade e Consenso. Constituição, Hermenêutica e Teorias Discursivas. 4ª Ed. São Paulo: Saraiva, 2011, p. 509-510 e 91.)

14 Por otra parte, un pleito, cualquiera que sea el procedimiento con arreglo al cual se sustancie, representa siempre más o menos una especie de batalla, cuyo resultado es imposible predecir de modo seguro. El éxito de la prueba condiciona a veces decisivamente el resultado de la contienda; y puede ocurrir que la parte que tenía plena razón, y a cuyo favor estaba sin duda el Derecho, pierda el pleito por no haber conseguido probar los hechos básicos. (SICHES, Luis Recásens. Nueva Filosofia de la Interpretacion del Derecho. Segunda Edicion. México:Editorial Porrúa, S.A., 1973, p. 310).

15 CAPPELlETTI, Mauro. Juizes Legisladores? Tradução: Carlos Alberto Álvaro de Oliveira. Porto Alegre: Sérgio Antônio Fabris Editor, 1993, p. 27 
Destaca-se como relevante que o Poder Legislativo, representante democrático, deve compreender que suas palavras de ordem comprometem o desenvolvimento de suas práticas, que precisam estar indissociavelmente ligadas a uma indeterminação última com respeito ao quadrinômio: poder-saber-leidesejo. Não podemos pretender a solução dos problemas humanos na certeza do pensamento, nas medidas justas dos sonhos esquematizados pela razão, dos sonhos armados, visivelmente arrogantes na postulação de suas respostas ${ }^{16}$.

Pelo evidenciado, a democracia imposta pelas sociedades contemporâneas ${ }^{17,18,19}$ busca, através de um processo substancialista via Poder Judiciário, a defesa de

16 WARAT, Luis Alberto. Introdução Geral ao Direito III: O Direito Não Estudado Pela Teoria Jurídica Moderna. Porto Alegre: Sergio Antonio Fabris Editor, 1955, p. 72-73.

17 A democracia, como sentido de uma forma de sociedade, depende de uma prática política (que não exclui a dimensão do sentido), capaz de transgredir a massa simbólica que faz do indivíduo escravo da heteronomia instituída. Este progresso transgressivo precisa, inclusive, subverter as difusas ideias que, na versão instituída da sociedade, operam como um uso definitório e alienado do sentido da democracia. A democracia, como sentido de uma forma social, não depende de nenhum sentido consagrado porque ela é, antes de mais nada, a dinâmica de uma imaginação produtiva, criadora e incerta, que ao mesmo tempo concretiza espaços de resistência e transgressão frente a um universo simbólico-institucional, que transforma a política em manipulação opressora, a economia em forma de exploração, o saber numa magia alienada que altera as práticas de construção das verdades em pretensas práticas de domínio do absoluto, e os desejos em respostas parasitárias a um consumo sem necessidade. (WARAT, Luis Alberto. Introdução Geral ao Direito III: O Direito Não Estudado Pela Teoria Jurídica Moderna. Porto Alegre: Sergio Antonio Fabris Editor, 1955, pp. 72-73).

18 A democracia, como sentido de uma forma de sociedade, depende de uma prática política (que não exclui a dimensão do sentido), capaz de transgredir a massa simbólica que faz do indivíduo escravo da heteronomia instituída. Este progresso transgressivo precisa, inclusive, subverter as difusas ideias que, na versão instituída da sociedade, operam como um uso definitório e alienado do sentido da democracia. A democracia, como sentido de uma forma social, não depende de nenhum sentido consagrado porque ela é, antes de mais nada, a dinâmica de uma imaginação produtiva, criadora e incerta, que ao mesmo tempo concretiza espaços de resistência e transgressão frente a um universo simbólico-institucional, que transforma a política em manipulação opressora, a economia em forma de exploração, o saber numa magia alienada que altera as práticas de construção das verdades em pretensas práticas de domínio do absoluto, e os desejos em respostas parasitárias a um consumo sem necessidade. (WARAT, Luis Alberto. Introdução Geral ao Direito III: O Direito Não Estudado Pela Teoria Jurídica Moderna. Porto Alegre: Sergio Antonio Fabris Editor, 1955, pp. 72-73).

19 No entanto, as sociedades contemporâneas parecem ter entrado numa nova fase. De um lado, assistimos à perturbação do conjunto dos equilíbrios sociais: revoluções tecnológicas (expansão das tecnologias de informação e de comunicação, desenvolvimento de biotecnologias), mutações do sistema produtivo (papel crescente desempenhado pela 
seus direitos calcando-se este nos princípios máximos de justiça e da equidade dos direitos fundamentais e dos valores e procedimentos democráticos, inclusive em face dos outros Poderes ${ }^{20}$. A matriz que se segue é a de que a legitimidade da Jurisdição por seu papel de reforço no processo democrático de elaboração da Lei para eventualmente corrigir os desvios do processo de representação popular $^{21}$.

Quanto essa função criadora do Direito pela via Jurisdicional revela-se por via de suas decisões jurídico-políticas que se tornam fontes seguras do ordenamento jurídico, as quais elevam os Juízes e Tribunais ao patamar de protagonismo, os tornando Ativistas Judiciais pela égide do substancialismo. Portanto, Kelsen alude que:
"A função criadora de Direito dos Tribunais é especificamente manifestada quando a decisão judicial tem o caráter de um precedente, ou seja, quando a decisão judicial cria uma norma geral. Onde os tribunais estão autorizados não apenas em aplicar Direito substantivo preexistente nas suas decisões, mas também a criar Direito novo para casos concretos, existe uma compreensível tendência de se dar a essas decisões judiciais o caráter de precedentes. Dentro de tal sistema jurídico, os tribunais são órgãos legislativos exatamente no mesmo sentido em que o órgão é chamado legislativo no sentido mais restrito e comum do termo". ${ }^{22}$

Supõe-se, desta forma, que os Juízes e as Cortes, ao aplicarem o Direito, o façam a partir de seu caráter dinâmico, de maneira facultada a estes a possibilidade de recorrer a critérios discricionários na concretização do Direito, por

informação, declínio da indústria em proveito dos serviços, deslocalização das unidades de produção, adaptação das formas de trabalho), transformações da estratificação social (refluxo do campesinato, explosão do mundo do operariado, multiplicação de empregos ditos intermediários), inflexão dos comportamentos e de relações sociais que, nas sociedades dominadas pela urgência e caracterizadas por uma dinâmica permanente de mudança, tendem a ser vividas sob o modo de instantaneidade, sob o signo do efêmero. Por outro lado, e correlativamente, assistimos a um movimento contraditório de concomitante radicalização e enfraquecimento do sistema de valores que foi a vanguarda e a base da modernidade. (CHEVALLIER. Jaçques. O Estado Pós-Moderno. Belo Horizonte: Fórum, 2009, pp. 16-17).

20 BARROSO, Luís Roberto. Judicialização, Ativismo Judicial e Legitimidade Democrática. Disponível em: <http://www.oab.org.br/oabeditora/users/revista/12350666 701 74218181901.pdf $>$. Acesso em: 12-06-2013.

21 BERIZONCE, Roberto Omar. Activismo Judicial y Participación en la Construcción de las Políticas Públicas. Civil Procedure Review, v.1, n.3: 46-74, sep./dec., 2010, pp. 47-48.

22 KELSEN, Hans. Teoria Geral do Direito e do Estado. $3^{\text {a }}$ ed. São Paulo: Martins Fontes, 2000, p. 216. 
intermédio de argumentos que visam políticas calcadas em direitos políticos individuais, difusos ou coletivos. Deste modo, as novas relações entre Direito e Política são tomadas como inevitáveis ao enriquecimento da agenda igualitária, que exige uma política ampla e complexa ${ }^{23}$ por parte do Poder Judiciário em sua defesa, assim tendo de um lado como função precípua: efetivá-las e concretizá-las, e de outro lado à criação de Direito para com a ampliação de políticas públicas para diminuir tais desigualdades. Incide assim a prevalência do Direito, por outros critérios que determinem a atividade jurisdicional, quais sejam os princípios de Direito e as diretrizes políticas ${ }^{24}$.

Conclui-se que a criação de Direito pelo Poder Judiciário deve ser claramente distinguida da criação de normas gerais através da prática permanente dos tribunais ${ }^{25}$, que o Direito passa a dar efetiva tutela jurisdicional substantiva por meio de princípios ${ }^{26}$.

23 Las desigualdades revisten un carácter territorial (regiones pobres/regiones ricas), un carácter económico (de la extrema riqueza, pasando por clases acomodadas, medias y pobres), sociológico (modos de vida) y sanitario (extrema desigualdad entre los que gozan de los avances de la cirugía, de la técnica, de la medicina y los que no). También cabe distinguir entre las desigualdades ligadas a las diversidades culturales, a las diversidades profesionales (están los que lo pasan bien en el ejercicio de su profesión y los que lo sufren como una obligación) y entre las profundas desigualdades en el destino de los que van a sufrir su vida y los que la van a disfrutar. Esas desigualdades no son sólo consecuencia de la cantidad de dinero que se posee. La riqueza no hace, necesariamente, la felicidad. Pero lo que sí es cierto es que la miseria provoca la desdicha. Una política de la humanidad no tiene como misión igualarlo todo y destruir la diversidad, sino que debe plantearse las vías reformadoras que permitirían reducir progresivamente las peores desigualdades. En resumen, el problema de las desigualdades ha crecido enormemente sin dejar de ser múltiple; exige una política amplia y compleja. Ésta, repitámoslo, no puede ser una política tecnoburocrática de homogenización, destructora de la diversidad que constituyen las riquezas culturales de la humanidad. (MORIN, Edgar. La Vía. Para el futuro de la humanidad. $1^{\text {a }}$ Ed. Barcelona: Paidos, 2011, pp. 109-110).

24 Quanto ao Poder Legislativo ele faz incidir a vontades do povo por meio da decisão majoritária dos grupos, e estes têm maior capacidade de impor seus interesses sobre os direitos das minorias, dificilmente os grupos minoritários conseguiriam alcançar esses direitos. Assim gerando desigualdade.

25 KELSEN, Hans. Teoria Geral do Direito e do Estado. 3ª ed. São Paulo: Martins Fontes, 2000, p. 217.

26 Assim, qualquer que pense, como eu, que a prestação jurisdicional substantiva no direito é uma questão de princípio, e que essa é uma importante afirmação tanto em termos normativos quanto teóricos, tem um interesse especial em saber se é possível encontrar um meio-termo entre as afirmações exageradas e as niilistas sobre os direitos que as pessoas têm a processos no tribunal. (DWORKIN, Ronald. Uma questão de Princípio. $1^{\text {a }}$ ed. São Paulo: Martins Fontes, 2001, pp. 113-114). 
Quanto aos argumentos de princípio, estes são destinados a estabelecer um Direito individual; os argumentos de política são argumentos destinados a estabelecer um objetivo coletivo. Os princípios são proposições que descrevem direitos; as políticas são proposições que descrevem objetivos. Um direito político é um objetivo político individualizado ${ }^{27}$. A Constituição se atenta à interface do Direito de um lado e do Político de outro, esforçando-se para submissão do Poder às categorias que mobilizam o Direito, como a Justiça, a Segurança e o bem-estar social. Sua interpretação, portanto, sempre terá uma dimensão política, ainda que balizada pelas possibilidades e limites oferecidos pelo ordenamento vigente ${ }^{28}$.

Neste tocante, a Justiça deve ser vista como um valor superior do ordenamento jurídico, representando um ideal para a comunidade, um objetivo a alcançar pelo ordenamento jurídico, por que se existe interesse público em que o resultado do processo seja justo, o Estado deve pôr a serviço dos juízes todos os meios e poderes necessários para que possam alcançar dito fim ${ }^{29}$. É na Constituição que este modelo substancialista toma força, pois ele emana de seus princípios básicos e imanentes, sendo que nestes estão esculpidos desde os Direitos Naturais dos Homens até a sua evolução, chegando ao ponto de se formarem como Direitos Fundamentais do Homem. Por tudo isso, lembra-se que as constituições dão liberdades aos julgadores para que decidam de forma aberta, por intermédio da Justiça Constitucional, gerando, com este ciclo, o que é mais adequado aos cidadãos ${ }^{30}$.

27 DWORKIN, Ronald. Levando os Direitos a sério. $1^{\text {a }}$ ed. São Paulo: Martins Fontes, 2002, pp. 141-142.

28 BARROSO, Luís Roberto. Judicialização, Ativismo Judicial e Legitimidade Democrática. Disponível em: <http://www.oab.org.br/oabeditora/users/revista/12350666 70174218181901.pdf >. Acesso em: 13-05-2013.

29 PICÓ i JUNOY. El Derecho Procesal entre el Garantismo y el eficácia: Un debate mal planteado. In: AROCA, Juan Montero (Coord.). Proceso Civil e Ideología. Un prefacio, una sentencia, dos cartas y quince ensayos. Valencia: Tirant to Blanch, 2006, p. 110.

30 O modelo substancialista - que, em parte, aqui subscrevo, ressalvando sempre o problema do fundamento da Constituição, que não pode ser entendida como uma categoria ou hipótese, proferindo entendê-la como um paradoxo - trabalha na perspectiva de que a Constituição estabelece as condições do agir político-estatal, a partir do pressuposto de que a Constituição é a explicitação do contrato social (contrato social também deve ser entendido a partir do paradigma hermenêutico, e não como um ponto de partida congelado). É o constitucionalismo-dirigente que ingressa nos ordenamentos dos países após a segunda guerra. Consequentemente, é inexorável que, com a positivação dos direitos sociais-fundamentais, o Poder Judiciário (e, em especial, a justiça constitucional) passe a ter um papel de absoluta relevância, mormente no que pertinente à jurisdição constitucional. (STRECK, Lenio Luiz. Jurisdição Constitucional e Hermenêutica - Uma nova crítica do direito. Porto Alegre: Livraria do Advogado, 2002, p. 141.) 
As questões Políticas se afirmam como sendo questões subjacentes, declaram-se como sendo principiológicas, e seus argumentos incidem sobre algumas preposições, sendo elas: a) A revisão judicial deve ter em vista o processo da legislação, não o resultado isolado desse processo; b) Ela deve avaliar esse processo segundo o padrão da democracia; c) A revisão baseada no processo, portanto, é compatível com a democracia, ao passo que a revisa baseada na substância, que tem em vista os resultados, é antagônica a ela; d) O Tribunal, portanto, erra quando cita um valor substantivo putativamente fundamental para justificar a revogação de uma decisão legislativa ${ }^{31}$.

Neste diapasão, há que se falar que a Constituição é, precisamente, o documento que transforma o Poder Constituinte em Poder Constituído, isto é, Política em Direito. Essa interface entre dois mundos ${ }^{32}$ dá à Interpretação Jurídica uma inexorável dimensão política. No entanto, o ativismo judicial consubstancia-se pelo substancialismo, encontrando-se inserido pelas Constituições Democráticas Contemporâneas, e assim fazem com que o Poder Judiciário exerça influência sobre os demais Órgãos Estatais: a) a aplicação direta da Constituição a situações não expressamente contempladas em seu texto e independentemente de manifestação do legislador ordinário; b) a declaração de inconstitucionalidade de atos normativos emanados do legislador, com base em critérios menos rígidos que os de patente e ostensiva violação da Constituição; c) a imposição de condutas ou de abstenções ao Poder Público, notadamente em matéria de políticas públicas ${ }^{33,34}$. As decisões do Poder Judiciário detêm cunho político-jurídico, que atingem as demais Esferas Públicas.

31 DWORKIN, Ronald. Uma questão de Princípio. $1^{\text {a }}$ ed. São Paulo: Martins Fontes, 2001, p. 81.

32 BARROSO, Luís Roberto. Judicialização, Ativismo Judicial e Legitimidade Democrática. Disponível em: <http://www.oab.org.br/oabeditora/users/revista/123506667017421 8181901.pdf>. Acesso em: 13-05-2013.

33 BARROSO, Luís Roberto. Judicialização, Ativismo Judicial e Legitimidade Democrática. Disponível em: <http://www.oab.org.br/oabeditora/users/revista/12350666 70174218181901.pdf>. Acesso em: 12-06-2013.

34 Entonces, los jueces no sólo se encuentran institucionalmente bien situados para enriquecer el proceso deliberativo y ayudarlo a corregir algunas de sus indebidas parcialidades. Los jueces poseen, además, diversas herramientas que facilitan su tarea al respecto. Como consecuencia de su posición institucional y de los medios con los que cuentan, los jueces tienen buenas probabilidades de favorecer el buen funcionamiento del proceso deliberativo. Al mismo tiempo, tienen amplias posibilidades de actuar de manera respetuosa hacia a la autoridad popular: ellos poseen suficientes técnicas y medios procedimentales a su alcance para actuar en consecuencia. Pueden bloquear la aplicación de una cierta norma y devolverla al Congreso, forzándolo a pensar de nuevo sobre ella; pueden declarar que algún derecho fue violado, sin imponer a los 
Somado a tudo isso, o juiz ativista ignora o texto da Constituição, a história de sua promulgação, as decisões anteriores da Suprema Corte que buscam interpretá-la e as duradouras tradições de nossa cultura política. ${ }^{35}$

O substancialismo notoriamente demonstra-se mais simpático àquilo que a Constituição Dirigente traz para o centro do debate jurídico, a política, e ainda "politiza" o conceito de Constituição, que não se limita mais à sua normatividade Com isto, cria um agradável nexo entre Direito, Moral e Política, suplantando defeitos do positivismo de outrora ${ }^{36}$. As questões políticas abordadas pressupõem que os cidadãos têm certos direitos morais contra o Estado, assim o Ativismo Judicial incidido pela corrente substancialista é um programa baseado, não pelos conceitos morais e éticos do juiz, mas busca no nascedouro das nações Ou seja, toma por base as Cartas Políticas, que estas têm direitos inscritos nos seus textos para que em caso de violação devem fazer valer sua fundamentação principiológica estabelecida nos precedentes/jurisprudências:

"O ativismo somente pode ser justificado como um programa baseado em algo mais que preferências pessoais dos juízes se, em algum sentido, esses direitos morais existem. A teoria cética ataca o ativismo em suas raízes, argumentando que, de fato, os indivíduos não têm tais direitos morais contra o Estado. Eles têm apenas os direitos jurídicos que a Constituição lhes assegura, e estes direitos se restringem às violações claras e inquestionáveis da moralidade pública que os constituintes devem efetivamente ter concebido ou as que desde então foram estabelecidas por uma sucessão de precedentes". ${ }^{37}$

No entanto, as sociedades modernas geram, na realidade, uma demanda pela Jurisdição Quantitativa e Qualitativa. Trata-se de uma demanda de massa

legisladores una solución concreta; pueden establecer que una violación de derechos debe ser corregida en un tiempo límite, sin ponerse en el lugar del legislador ni decidir cuál remedio particular debería ser aprobado; pueden sugerir al legislador una serie de remedios alternativos, dejando la decisión final en las manos del último. (GARGARELLA, Roberto. Democracia deliberativa y el papel de los jueces frente a los derechos sociales. Disponível em: <http://new.pensamientopenal.com.ar/01102010/derechoshumanos02. pdf $>$. Acesso em: 06-09-2012.

35 DWORKIN, Ronald. O Império do Direito. $1^{\text {a }}$ ed. São Paulo: Martins Fontes, 1999, pp. 451-452.

36 SILVA, João Fernando Vieira da. O resgate da ideia de constituição dirigente no constitucionalismo pátrio. Disponível em: <http://www.mundojuridico.adv.br >. Acesso em: 03-05-2013.

37 DWORKIN, Ronald. Levando os Direitos a sério. $1^{\text {a }}$ ed. São Paulo: Martins Fontes, 2002, pp. $216-217$ 
e de uma demanda maciça ${ }^{38}$, que coadunam com os princípios legais, sociais e políticos, habitando o pensamento de muitos teóricos do direito ${ }^{39}$.

Deste modo, o Poder Judiciário torna-se o centro gravitacional de negociações, pois as sociedades passam a pleitear direitos buscando, assim, a obtenção de uma decisão judicial favorável. E ainda, demonstra-se aberto às demandas sociais, as quais o Direito precisa de legitimidade social por uma ordem legal, isto é, por uma Jurisdição Substantiva, que somente o Direito seria capaz de oferecer ${ }^{40}$.

\section{O Ativismo judicial pela corrente substancialista}

O Ativismo Judicial se realiza pela corrente Substancialista, o qual se usa- da Interpretação calcada na Hermenêutica Jurídica de cunho filosófico ${ }^{41}$, transformando o juiz no mais importante ator do cenário Sócio Jurídico, passou o mesmo a ser protagonista da realidade que lhe é imposta pela experiência adquirida jurisdicionalmente em que a democracia e as práticas políticas dos direitos humanos vinculam-se às problemáticas que suscitam as tarefas de formação de um espaço público emancipatório ${ }^{42}$.

38 GARAPON, Antoine. O juiz e a democracia. O guardião das promessas. Tradução: Maria Luiza de Carvalho. 2a ed. Rio de Janeiro: Revan, 2001, p. 139.

39 Com efeito, para que o judiciário se aproxime do lugar de elemento chave em tal democracia "não utópica" proposta por Cappelletti, o direito precisa de sustentabilidade e legitimidade social frente a demandas por uma ordem legal mais efetiva, isto é, por uma justiça substantiva, justiça essa que o direito, engessado pelo formalismo e legalismo jurídicos, seria incapaz de oferecer. AGUIAR, Thais Florencio de. A judicialização da política ou o rearranjo da democracia liberal. Ponto-e-Vírgula, 2: 142-159, 2007, p. 150. Disponível em: <http://www.pucsp.br/ponto-e-virgula/n2/pdf/11-thais.pdf>. Acesso em: 13-07-2013.

40 Garantir as políticas públicas, impedir o desvirtuamento privatista das ações estatais, enfrentar o processo de desinstitucionalização dos conflitos - apenas para arrolar algumas hipóteses de trabalho - significa atribuir ao magistrado uma função ativa no processo de afirmação da cidadania e da justiça substantiva. Aplicar o direito tende a configurarse, assim, apenas num resíduo de atividade judiciária, agora também combinada com a escolha de valores e aplicação de modelos de justiça. Assim, o juiz não aparece mais como o responsável pela tutela dos direitos e das situações subjetivas, mas também como um dos titulares da distribuição de recursos e da construção de equilíbrio entre interesses "supra individuais". (STRECK, Lenio Luiz. Jurisdição Constitucional e Hermenêutica Uma nova crítica do direito. Porto Alegre: Livraria do Advogado, 2002, p. 32.)

41 Tanto o Ativismo Judicial quanto a Interpretação Judicial do Direito realizada pela Hermenêutica Jurídica de cunho filosófica apresentam um ponto sensível e comum, pois consideram-se antiformais.

42 Considere assim, que a representação da realidade e a produção institucional da subjetividade como as formas iniciais da política. De fato, existe uma semiose do poder 
"Os juízes desenvolveram uma abordagem particular da interpretação jurídica formando e aperfeiçoando uma teoria política sensível a essas questões, de que dependerá a interpretação em casos específicos, e chama isso de sua filosofia jurídica. Ela incluirá características estruturais, que elaborem a exigência geral de que uma interpretação se ajuste à história doutrinal, e afirmações substantivas sobre os objetivos sociais e os princípios de justiça. A opinião de um juiz sobre a melhor interpretação será, portanto, a consequência de convicções que outros juízes não precisam compartilhar". ${ }^{43}$

Reconheceu-se que realmente o juiz cria direito de modo transparente, o qual o Ativismo Judicial, consubstanciado pela corrente Substancialista, tem sido extraordinariamente beneficente para que se venha a romper o formalismo do Direito, abrindo novos espaços diante do ordenamento jurídico.

Pelo que foi exposto, é necessário apontar que o procedimentalismo, pela sua natureza de legitimação do Direito Legislativo, passou a incidir no Judiciário pelo substancialismo. Assim, o primeiro gerou viabilidade Legitimadora para que o segundo venha a existir, pois aquele serve de via de acesso e vem a garantir os meios democráticos de participação das sociedades, assim reveste-se em tal o substancialismo.

\section{A Politização do direito pela via judicial ${ }^{44,45}$}

"El nuevo nivel (espesos e intensidad) en la revelación Jueces-DerechoPolítica. Del magistrado neutral al comprometido (ativista)" ${ }^{46}$

que produz o real, domínios de objetos e rituais de verdade e de desejo. Poderes que se exercem positivamente para a fabricação institucional da vida: homens produzidos por um poliforme que os enclausura num horizonte uniforme de utopias perfeitas. Neste tocante a grande transformação da sociedade passa pelas mudanças na forma de representação da realidade e da produção da subjetividade. Partindo dessa tese, falo da democracia e das práticas políticas dos direitos humanos vinculando as problemáticas que suscitam as tarefas de formação de um espaço público emancipatório. (WARAT, Luís Alberto. Introdução Geral ao Direito III: O Direito Não Estudado Pela Teoria Jurídica Moderna. Porto Alegre: Sergio Antônio Fabris Editor, 1955, p. 74.)

43 DWORKIN, Ronald. Uma questão de Princípio. $1^{\text {a }}$ ed. São Paulo: Martins Fontes, 2001, pp. 24-242.

44 Porque es inútil querer disociar el poder judicial de los otros poderes del Estado, el legislativo y el ejecutivo, con el pretexto de que éstos representan el poder político, en tanto que el poder del juez tendría naturaleza jurídica exclusivamente. En primer término, es un error oponer el derecho -el derecho del Estado- a la política: el derecho, regla establecida por la sociedad política, está ordenado necesariamente a los fines de la política. Por tanto, en la medida en que los tribunales 
Antes de adentrar propriamente no assunto vem se indagar: ¿Se puede creer que edictos y fórmulas técnicamente perfectos, fuesen obra de un magistrado que podía ser un eminente político y al mismo tiempo ignorante en materias jurídicas? ${ }^{27}$

A resposta é negativa, pois no plano da formulação-criação do Direito, não há como o direito ser separado da política, na medida em que é produto do processo constituinte ou do processo legislativo, isto é, da vontade das maiorias. O Direito é, na verdade, um dos principais produtos da política, o troféu pelo qual muitas batalhas são disputadas. Em um Estado de Direito, a Constituição e as Leis, a um só tempo, legitimam e limitam o Poder Político ${ }^{48}$.

han de elaborar el derecho será preciso que lo hagan en función del Estado y de sus fines; lo que es la misión de la politica. Y después es ilógico el separar de la política el poder judicial cuando este último tiene comprencia -en caso de laguna legal- para suplir al poder legislativo, que es poder esencialmente político. Se sabe, por lo demas, cómo funciona esa suplencia: acaba por instituirse una jurisprudencia, que de hecho es equivalente a la ley esta equivalencia de hecho -equivalencia de derecho en los países de Judge made law [el juez hace derecho]- es la que confiere valor cuasi legislativo a los principios de derecho jurisprudencial establecidos poco a poco por tribunales partiendo de los casos concretos. (BADIN, Jean. Teoría General del Derecho. Madrid: Editorial Revista de Derecho Privado, 1995, pp. 34-35.)

45 Temos reiterado, ao longo deste nosso trabalho, a convicção de que o Direito é importante para conformar a vida social, só lhe cumprindo a função de compor conflitos que nela se configurarem, quando não resolvidos por outros meios socialmente institucionalizados e admissíveis. Porque assim é, relaciona-se necessariamente a determinada organização política da convivência humana, se não for mais exato dizer-se que esta é que lhe define o conteúdo, resultado do efetivo confronto das forças sociais que esses grupos organizados operam. O processo de produção do Direito, por conseguinte, é sempre dependente da realidade social que buscar ordenar e a ela funcionalmente se vincula, objetivando emprestar-lhe segurança, mediante a predeterminação e institucionalização de modelos ou esquema de solução de conflitos coercitivamente aplicáveis aos casos concretos. A produção do Direito, portanto, sempre foi reservada, e sempre o será, aos que, no grupo, se mostrem aptos a monopolizar o uso legitimo de força. Tenham sido eles os chefes de família gregos ou romanos, o patriarcado ou a aristocracia, a burguesia ou os estamentos burocráticos dos partidos únicos, se hegemônicos, monopolizarão o processo de produção do Direito. (PASSOS, J. J. Calmon de. Direito, Poder, Justiça e Processo. Julgando os que nos Julgam. Rio de Janeiro: Forense, 1999, p. 93.)

MORELLO, Augusto M. El Derecho y Nosotros. La Plata: Librería Editora Platense, 2000, p. 17.

BIONDI, Biondo. Arte y Ciencia del Derecho. Barcelona: Ediciones Ariel, 1953, p. 140.

A separação entre Direito e política tem sido considerada como essencial no Estado constitucional democrático. Na política, vigoram a soberania popular e o princípio 
Desta forma, a Politização do Direito pela via judicial, faz emergir um novo paradigma no qual o juiz transformou-se em partícipe da sociedade e defensor da democracia por meio da prestação jurisdicional, onde a Jurisdição passa a provocar transformações políticas, sociais e econômicas. O mais relevante é afirmar que o Ativismo Judicial transforma o Direito em seu amago, por meio da Política ${ }^{49}$.

majoritário. O domínio da vontade. No Direito, vigora o primado da lei (the rule of law) e do respeito aos direitos fundamentais. O domínio da razão. A crença mitológica nessa distinção tem resistido ao tempo e às evidências. Ainda hoje, já avançado o século XXI, mantém-se a divisão tradicional entre o espaço da política e o espaço do Direito. Essa separação é potencializada por uma visão tradicional e formalista do fenômeno jurídico. Nela se cultivam crenças como a da neutralidade científica, da completude do Direito e a da interpretação judicial como um processo puramente mecânico de concretização das normas jurídicas, em valorações estritamente técnicas. Tal perspectiva esteve sob fogo cerrado ao longo de boa parte do século passado, tendo sido criticada por tratar questões políticas como se fossem linguísticas e por ocultar escolhas entre diferentes possibilidades interpretativas por trás do discurso da única solução possível. Mais recentemente, autores diversos têm procurado resgatar o formalismo jurídico, em uma versão requalificada, cuja ênfase é a valorização das regras e a contenção da discricionariedade judicial. (BARROSO, Luís Roberto. Jurisdição Constitucional: A Tênue Fronteira Entre o Direito e a Política. Disponível em: < www.migalhas.com.br/arquivos/2014/2/ art20140204-06.pdf>. Acesso em: 03-09-2013, pp. 15 e 16.)

Há uma grande contradição no encontro da decisão judicial com a Política, são como dois elementos que, na linguagem do paradigma liberal do Direito e do Estado, pertencem a esferas diferentes e não podem se encontrar. São dois fenômenos cuja relação causa impacto no observador por precisamente não carregarem consigo nenhuma partilha no conhecimento jurídico acumulado, salvo a condição própria de serem compreendidos em separado, em um mundo comum, no qual, todavia, vivem. Este constrangimento da permanência e relacionamento no mesmo mundo se expressa da maneira mais simples e necessária no debate presente sobre a politicidade das decisões judiciais. Há sempre, de um lado, uma impossibilidade habitando na questão de fundo da legalidade e, de outro, a exigência premente de não olvidar o possível e perder de vista o objetivo da fundamentação substantiva das decisões judiciais na era da complexidade da Sociedade e do exaustivo debate sobre a questão dos direitos fundamentais. A esfera judicial vem apresentando cada vez maior articulação com a esfera política, originando um intenso debate sobre o alcance e possibilidades dessas conexões. Por um tempo vigorou o modelo desejável de um processo deliberativo atento à promoção da Democracia com forte ênfase nos compromissos democráticos dos agentes das decisões judiciais. Hoje a discussão é mais ampla e, paradoxalmente, atinge a própria legitimidade jurisdicional para tomar decisões de caráter político, o que leva necessariamente ao estudo do grau de politicidade de suas deliberações. (MONTEIRO, Cláudia Servilha. A racionalidade da decisão judicial política. In: Revista Brasileira de Estudos Políticos, p. 193.) 
Neste sentido, ocorre o abandono da preservação da Juridicidade do sistema que vem a possibilitar a invasão da corrente substancialista como critério ideológico político, sujeitando-se igualmente a voluntarismos e discricionariedades daqueles destinados a expressar o conteúdo de uma Decisão Política ${ }^{50}$.

No tocante a Política, esta pode ser vista em duas perspectivas: a) como ciência, a mesma mostra o Estado e circunstâncias de determinado povo diante das leis sociologias; b) como arte ${ }^{51}$, pois ela serve ao descobrimento, empírico, ou experimental indutivo, dos meios técnicos mais próprios ao Governo e às relações de ordem jurídico estatal no momento ou período que ele vive. Resta evidente que todas as Constituições Contemporâneas precisam ser obras editadas, profundas, tanto da ciência como da arte política, de ciência jurídica e de técnica jurídica ${ }^{52}$.

Neste sentido, "la politica si può in un certo senso considerare como la gestazione del diritto: un accavallarsi di correnti inquiete che cercanno di aprirsi un varco per arrivare a trovar appagameto e riposo in leggi che le riconoscano e le tutelino. Tutte le critiche rivolte controgli ordinamenti invecchiati, la lotta contro le istituzioni, le aspirazioni delle classi sacrificate, le sommosse e le rivoluzioni, si ruducono, per chi le consideri sotto l'aspetto giuridico, a movimenti di interessi disconosciui e conculcati dalle leggi vigenti, che lottano per l'abolizione di esse e per la creazione al loro posto di altre leggi che trasformino questi interessi

50 Enquanto Hans Kelsen juridiciza o poder, Carl Schmitt pretende na sua construção epistemológica a politização do Direito, a partir de uma teoria material da Constituição. Cumpre ressaltar a importância que se confere ao sentido de Constituição enquanto vetor de interpretação, cujo resultado tem influência direta sobre a pluralidade normativa que, em dado ordenamento, se enfeixa na unidade do sistema constitucional. (PORTO, Noemia Aparecida Garcia. O Juiz no contexto da interpretação jurídica. Bimestral. Ideias Legais - Ano 1 - $\mathrm{n}^{\circ} 4$ - julho e agosto. Campo Grande - MS: Escola Superior da Magistratura da $24^{a}$ Região, 2005, pp. 27-28 e 30.)

51 La dirección del Estado no puede ser anónima: la ocupación del poder necesita un arte que tiene como nombre político. La política supera a la cibernética del aparato; es el dominio de la decisión, de la elección, de las estrategias de acción interior y exterior, y necesita reflexión, consejo, debate, consciencia, voluntad de individuos responsables. Es un arte complejo, incierto y decisivo que, en los momentos críticos y críticos, compromete a la sociedad por entero. Y, e el riesgo y el alea, toda sociedad, incluso democrática, necesita jefes responsables. Los jefes pueden identificarse con su función y consagrarse al servicio de la sociedad, pero al mismo tiempo pueden convertirse en parásitos que ponen el poder a su servicio. (MORIN, Edgar. El Método: La Humanidad de la Humanidad. La Identidad Humana. $1^{\text {a }}$ Ed. Madrid: Catedra Teorema, 2003, pp. 202.)

52 MIRANDA, Pontes de. Fundamentos Actuales do Direito Constitucional. Vol. I. Rio de Janeiro: Collecção de Cultura Social, 1932, p. 29. 
in diritti. Ogni attività politica, anche estrema e sovvertitrice, mir a creare un ordine nuevo che sia consacrato in leggi: la politica è la dinamica di cui il diritto è la stasi e l'acquetamento". ${ }^{53,54}$

Conclui-se que, tanto no Direito quanto na Política, como em todas as ciências, é preciso acompanhar o movimento do espirito humano ${ }^{55} 56$. Portanto,

53 CALAmANDREI, Piero. Opere Giuridiche. Volume Terzo. Napoli: Morano Editore, 1968, p. 69

54 En el interior de la vida política hay sitio para el derecho, o mejor todavía, necesidad del derecho. Costumbres, leyes, procesos e instituciones jurídicas de una comunidad son importantes elementos de aquella identidad supraindividual del nosotros y de la subsiguiente familiaridad intersubjetiva. Tales hechos jurídicos son, por su estabilidad, garantía de la duración en el tiempo de la citada identidad supraindividual. Cada ordenamiento jurídico nacional encuentra su fundamento en una constitución. Una constitución no es otra cosa que la traducción y consagración en normas jurídicas del tipo de régimen político propio de la comunidad. Para la política, el derecho es un instrumento de movilidad, además de duración. Mejor derecho, de movilidad en la duración. Según la teoría institucionalista, no solo es cierto que donde hay sociedad allí hay derecho, sino que simplemente, no hay derecho sino allí donde una sociedad. (COTTA, Sergio. Que es el Derecho. Madrid: Rialp, 2000, pp. 8-9.)

55 MIRANDA, Pontes. Fundamentos Actuales do Direito Constitucional. Vol. I. Rio de Janeiro: Collecção de Cultura Social, 1932, p. 29.

56 La palabra "política" se atribuye actualmente a cualquier tipo de actividad humana: moda, economía, industria, etc., pero se advierte su distinto significado cuando le atribuimos un fin. Cada uno de nosotros mantenemos una identidad individual en cuanto seres pensantes, pero no dejamos de ser conscientes de esa identidad colectiva que nos agrupa socialmente desde el momento en que nos vemos como seres finitos o limitados. El aspecto social, la identidad colectiva del hombre constituye el ambiente humano de la política. El hombre es un animal político. La política no puede ser emparentada con el sinónimo de poder, ya que éste, por sí mismo no existe. El poder no es más que un elemento de la conciencia colectiva. De hecho, el poder se manifiesta usualmente como servidor de la comunidad. Si el poder no se apoya en la conciencia común, estaremos ante la opresión ignorante del sentir social o colectivo. Lo específico del valor político es ser común a un grupo humano, por lo cual, la expresión idónea para designarlo es la tradicional del bien común. Lo que importa en el bien común, desde el punto de vista de la vida política es precisamente, que es común, y está, por tanto, en disposición de conferir esa identidad supraindividual que aumenta la estatura del individuo. La importancia del elemento comunitario en la vida política se ha puesto de manifiesto de muchas maneras. En el plano lingüístico, en expresiones como patria, La misma palabra remite a cierto bien común. Incluso, pensemos en el constante uso de los símbolos, la bandera, el himno. Todos tienen un significado de reclamo unitario, como símbolos de la unidad supraindividual. La res pública, en cuanto a res populi encuentra en los símbolos expresión de su existencia y capacidad 
a política ganha legitimidade funcional por mediação da Constituição ${ }^{57,58}$, pois ela é o centro gravitacional que serve de motor que impulsiona ${ }^{59}$ o processo de todo o sistema jurídico-político ${ }^{60}$.

Superada as primeiras digressões, deve-se notar que, pela imposição natural das transformações ocorridas diante do Estado, vieram a incidir na contempora-

para recoger en un nosotros consciente a individuos distintos entre sí. También las clases sociales recuperan esos elementos, más influyentes cuanto más se sientan y actúen aquellas como actores políticos. Quienes plantean la política en términos clasistas insisten en la necesidad de la conciencia de clase, conciencia de un precisó nosotros y de un preciso bien común de la clase. Esos elementos de la política se hallan en cualquier tipo de agrupación política y en cualquier tipo de acción política, puesto que son elementos estructurales y no circunstanciales del vivir político. (COTTA, Sergio. Que es el Derecho. Madrid: Rialp, 2000, pp. 7-8.)

57 É a diferença entre Direito superior, a Constituição, e o demais Direitos, que acopla estruturalmente Direito e Política, possibilitando o fechamento operacional, a um só tempo, do Direito e da Política. Em outros termos, é por intermédio da Constituição que o sistema da Política ganha legitimidade operacional e é também por meio dela que a observância ao Direito pode ser imposta de forma coercitiva. (OLIVEIRA, Andrade Cattoni de. (Coordenação). Jurisdição e hermenêutica constitucional no Estado Democrático de Direito. Belo Horizonte: Editora Mandamentos, 2004, p. 25.)

58 Constituição, e cuja realização deve o juiz assumir como responsabilidade correspondente ao papel que exerce no Estado Constitucional, e que é valorizado a partir da prática interpretativa - potencializada pela familiaridade de um estudo constante - construtora, e não criadora, da normatividade. Isso implica em juízes engajados na prática do Direito, em busca de soluções inovadoras e edificantes para a construção do ambiente constitucional a partir da interpretação. (PORTO, Noemia Aparecida Garcia. O Juiz no contexto da interpretação jurídica. Bimestral. Ideias Legais - Ano 1 - $\mathrm{n}^{\circ} 4$ - julho e agosto. Campo Grande - MS: Escola Superior da Magistratura da 24a Região, 2005, pp. 44-45.)

59 Neste sentido, como refere M. Barberis: um juiz "de esquerda" pode interpretar um artigo da Constituição no sentido de este permitir uniões homossexuais, enquanto que, para um outro juiz "de direita", esse artigo as proíbe. (HESPANHA, António Manuel. Ideias sobre a Interpretação. In: NARVÁEZ, José Ramón; MONTEROS, Javier Espinoza de los. (Coord.). Interpretación Jurídica: Modelos Históricos y Realidades. Instituto de Investigaciones Jurídicas. Serie Doctrina Jurídica, Núm. 601. México: Universidad Nacional Autónoma de México, 2011, p. 36.)

60 Esse processo político não é eliminado da Constituição, configurando antes um elemento vital ou central no mais puro sentido da palavra: ele deve ser comparado a um motor que impulsiona esse processo. Aqui, verificam-se o movimento, inovação, a mudança, que também contribuem para o fortalecimento e para a formação do material da interpretação constitucional, porque, no seu quadro, são criadas realidades públicas e, muitas vezes, essa própria realidade é alterada sem que a mudança seja perceptível. (HABERLE, Peter. Hermenêutica Constitucional. Tradução: Gilmar Ferreira Mendes. Porto Alegre: Fabris Editor, 1997. Reimpressão 2002, p. 26.) 
neidade a invasão da Política no Direito, consubstanciada tal invasão pelo Poder Judiciário que faz conjecturar que o Direito é um empreendimento Político ${ }^{61}$. O Poder Judiciário, impulsionado pelo fenômeno Ativista realizado por sua função jurisdicional em suas sentenças-decisões que podem ser chamadas de Decisões Políticas, visam atingir um objetivo coletivo, para com a sociedade e indivíduo, exercendo desta forma o Poder Político o qual é detentor por meio de suas funções. O Ativismo Judicial dimensiona-se, assim, meio a uma transferência acentuada de Poder Político para Juízes e Tribunais frente à função jurisdicional que lhes é atribuída, e que por derradeiro acabam por promover alterações significativas na linguagem, na argumentação e no modo de participação da sociedade por absorverem acentuadamente a consciência popular ${ }^{62}$.

Corrobora-se que:

"In questo sistema di produzione giuridica, che possiamo chiamare sistema della formulazione giudiziaria del diritto, il giudice è posto direttamente a contatto colla coscienza popolare, nella quale il diritto flutua allo stato di sentimento, non ancora fissato i precise norme razionali, e, da quella oscienza di cui egli stesso è partecipe come menbro della consociazione, il gudice attinge la ispirazione per risolvere di volta in volta, secodo principi che egli non crea ma che gia trova esistenti in sè, le controversie che si presentano al suo giudizio: talchè, nessuno schermo intermedio frapponendosi fra il diritto e il giudice, questi si trova continuamente a contatto colla viva e fresca realtà

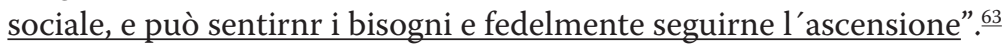

A Política que se projeta no Direito pela via Jurisdicional tem como finalidade geral, se é que tem alguma, coordenar o esforço social e individual, resolver

${ }_{61}$ DWORKIN, Ronald. Uma questão de Princípio. $1^{\text {a }}$ ed. São Paulo: Martins Fontes, 2001, p. 239.

62 BARROSO, Luís Roberto. Judicialização, Ativismo Judicial e Legitimidade Democrática. Disponível em: <http://www.oab.org.br/oabeditora/users/revista/12350666701 7421818190

1.pdf $>$. Acesso em: 12-01-2013.

63 Ma questa contrapposizione tra giustizia e política, che è necessaria nel sistema della legalità, sparisce nel sistema del diritto libero; se nel sistema della formulazione legale il giudice deve essere soltranto un giurista, cioè un interprete fedele del diritto già fissato in formule dal legislatore, nel sistema della formulazione giudiziaria il giudice deve per forz essere un político: perchè, non trovando dinanzi a sè la gui delle leggi precostituite, è costretto a cercar per suo conto i criteri di decisione nel tentar caso per caso quella diagnosi delle forze sociali nel sistema della legalità à fata per classi dal legislatore. (CALAMANDREI, Piero. Opere Giuridiche. Volume Terzo. Napoli: Morano Editore, 1968, pp. 14-15 e 70.) 
disputas sociais e individuais, assegurar a Justiça entre os cidadãos e entre eles e seu Governo, ou alguma combinação dessas alternativas ${ }^{64}$.

No entanto, os assuntos levados aos juízes e tribunais apresentam grande relevância social e serão agendados e definidos na decisão judicial, já que os demais poderes do Estado se negaram de solucioná-los pela sua omissão, deste modo tais assuntos, passam a integrar as decisões de cunho político.

Saliente-se que a interpretação do Direito realizada pelo Juiz-Tribunal carrega em sua essência uma forte valoração política, revelando uma sociedade livre e aberta que vem a potencializar com aptidão a oferecer alternativas para a interpretação ${ }^{65}$ do Direito. Tem por escopo ordenar o esforço social e individual, para que se deliberem as disputas sociais e individuais, fazendo assim com que ocorra a realização da Justiça entre os Cidadãos e entre o seu Governo.

"In un significato ampio, la politica abbracia tutte le attività pratihe che concorrono a creare l'ordine nella società: e quindi, anche nel sistema della divisione dei poteri, si può considerare política tanto 'attività degli organi legislativi che formulano il diritto in astratto, quanto quella degli organi giurisdizionali, che lo fanno valre applicandolo ai casi concreti. Ma nella contrapposizione tra giustizia e politica, che si suol fare quando si vuol affermare che questa seconda atività non deve intralciare l'esercicio della prima, alla parola politica si dà un significato più ristretto e specifico: adoprandola per indicare, in contrapposto all'attività giuridica che tutta si svolge nei limiti ed in esecuzione del diritto vigente accettato senza discuterlo cosí com'è, tutte quelle attività che, discutendo criticamente il diritto vigente, precedono e preparano la creazione del diritto futuro. Antitesi fra giustizia e poliitca significa dunque antitesi fra ius conditum e ius condendum: fra la osservanza del diritto vigente fedelmente interpretato, e la polemica per mettere al posto del diritto vigente un dirirro nuovo che sia più adeguato alle mutate esigenze storiche della società". ${ }^{66}$

Desde muito tempo ocorre certa relação tensa entre o Direito e a Política. E assim, o Juiz ou Tribunal aplicam certamente o Direito; mas a aplicação

64 DWORKIN, Ronald. Uma questão de Princípio. $1^{\text {a }}$ ed. São Paulo: Martins Fontes, 2001, p. 239.

65 HABERLE, Peter. Hermenêutica Constitucional. Tradução: Gilmar Ferreira Mendes. Porto Alegre: Fabris Editor, 1997. Reimpressão 2002, p. 43.

66 CALAMANDREI, Piero. Opere Giuridiche. Volume Terzo. Napoli: Morano Editore, 1968, pp. 68-69. 
deste Direito acarreta consigo necessariamente que aquele que o faz proceda a valorações políticas ${ }^{67}$.

De tudo, subsiste um conflito inegável entre democraticidade-legalidade ${ }^{68,69}$ e um cognitivismo ético subjacente à criação judiciário do Direito, e não se trata apenas de um conflito de natureza académica, pois frequentemente traduz questões de opção política ${ }^{70} \cdot{ }^{71}$.

67 BACHOF, Otto. Estado de Direito e Poder Político. Boletim da Faculdade de Direito de Coimbra. Vol. LVI. Coimbra: Coimbra Editora, 1996, p. 10.

68 En resumen: la fórmula Estado de Derecho expresa una relación parasitaria entre política y derecho. El sistema político se beneficia con el hecho de que en otra parte (en el derecho) se encuentra codificada y administrada la diferencia entre lo que es conforme a derecho/y lo discrepante. A la inversa, el sistema jurídico se beneficia con el hecho de que la paz -la diferencia de poderes claramente establecida y el hecho de que las decisiones se puedan imponer por la fuerza- está asegurada en otra parte: en el sistema político. (LUHMANN, Niklas. El Derecho de la Sociedad. México: Universidad Iberoamericana, 2002, p. 304.)

69 Más compleja es la diferencia entre derecho y política, puesto que en la sociedad moderna la mayor parte de las leyes son, sin duda, expresión de una voluntad política. No es difícil, sin embargo, demostrar que no existe una perfecta y constante coincidencia entre derecho y política. (COTTA, Sergio. Que es el Derecho. Madrid: Rialp, 2000, p. 2.)

70 HESPANHA, António Manuel. Ideias sobre a Interpretação. In: NARVÁEZ, José Ramón; MONTEROS, Javier Espinoza de los. (Coord.). Interpretación Jurídica: Modelos Históricos y Realidades. Instituto de Investigaciones Jurídicas. Serie Doctrina Jurídica, Núm. 601. México: Universidad Nacional Autónoma de México, 2011, p. 36.

71 En definitiva, ¿qué es una cuestión política? ¿Es posible distinguir lo político y lo jurídico o son dos caras de la misma moneda? El dictado de toda norma jurídica, salvo normas como las leyes de tránsito que resuelven simples problemas de coordinación social, implica una decisión política y la mayor parte de las decisiones políticas vinculantes tienen su expresión en normas jurídicas. Entonces, ¿cuál es este criterio de distinción entre cuestiones políticas y cuestiones jurídicas que nuestra Corte Suprema, a diferencia de la Corte Suprema norteamericana ha llevado lejos? Tal vez existe una intuición subyacente al tema de las cuestiones políticas y que, quizás, podría ser captada por una distinción que ha hecho hace algunos años el profesor Ronald Dworkin. Dworkin distingue dos tipos de razones o de argumentos que se dan en el ámbito jurídico, por un lado, los argumentos fundados en los derechos individuales: el derecho a la vida, el derecho a la seguridad personal, etc. Por otro lado, los argumentos basados en lo que él llama objetivos sociales colectivos, como por ejemplo un argumento basado en la defensa, en la seguridad pública, en la necesidad de aumento o no de la población, etc. ¿Cuál es la diferencia entre argumentos basados en derechos y los argumentos basados en políticas o en objetivos sociales colectivos? (NIÑO, Carlos S. La Filosofía del Control Judicial de Constitucionalidad. In: Revista del Centro de Estudios Constitucionales. Núm. 4. Septiembre-diciembre, 1989, pp. 82-83.) 
É necessário articular que aos juízes cabe a interpretação jurídica e que esta refletirá em uma teoria política Assim, efetiva-se o Ativismo Judicial, o qual por várias características estruturais passam a elaborar a exigência de uma interpretação mais ajustada em conformidade com questões substancialistas que refletem diretamente os objetivos sociais, políticos e morais ${ }^{72}$. Realiza também princípios de Justiça. Deste modo, o Judiciário serve de palco na busca por justiça, igualdade efetiva e por concretização dos direitos fundamentais ${ }^{73}$.

Com o advento do Estado Democrático de Direito, as realidades sociais democráticas emergem complexidade na contemporaneidade das decisões tomadas pelo Poder Judiciário, até então jurídicas, sobrecarregam-se na atualidade de questões com largo alcance político e social, as quais acabavam criando Direito pela via Jurisdicional fenômeno este pode ser chamado de Ativismo Judicial ${ }^{74}$ que vem a superar instâncias políticas tradicionais ${ }^{75,76}$.

72 Os direitos políticos são criações tanto da história, quanto da moralidade: aquilo que um indivíduo tem direito, na sociedade civil, depende tanto da prática quanto da justiça de suas instituições políticas. Desse modo, desaparece a alegada tensão entre originalidade judicial e história institucional: os juízes devem fazer novos julgamentos sobre os direitos das partes que se apresentam, mas esses direitos políticos antes refletem as decisões políticas tomadas no passado do que a elas se opões. (DWORKIN, Ronald. Levando os Direitos a sério. $1^{\text {a }}$ ed. São Paulo: Martins Fontes, 2002, p. 136.)

73 En síntesis: por una parte, la debilitadora retirada y prescindente comportamiento del Estado no obstante ser (debe ser) el motor clave de los equilibrios sociales. Por la otra, la Justicia ejerce o reconduce programas de gobierno, les da sentido, posibilidades, fijeza. Ahora los jueces y lo más trascendente la Corte Suprema ya no se limitan a definir o componer conflictos, controversias, casos. Su tarea, fundamentalmente la formativa y docente, ha subido a otro nivel de amplísimas direcciones y significación institucional. (MORELlO, Augusto M.. El Derecho y Nosotros. La Plata: Librería Editora Platense, 2000, p. 19.)

74 Così, affinchè il diritto, dalla coscienza socieale in cui vive allo stato inorganico, possa giungere a trasformarsi in sentenza, ocorrono qui due tappe lladdovve nelle consociazioni primitive bastava una tappa sola: tra il giudice e il diritto, che nella sua realtà sociele è qualcosa di vivo, di mutevole, di perghovole, si è frapposto ormai uno schermo rigido e fisso, che si chiama la legge, dalla quale il giudice non può torcere gli occhi per peragonarla colla società di cui essa si dice espressione, per accertarsi se veramente essa abbia tenuto conto di quegl'interessi e di quei sentimenti colletitivi, che dovrebbero formare il suo contenuto sostanziale. Questo non significa che, nel sistema della formulazione legislativa del diritto, il diritto si identifichi colla legge; al contrario, la legge resta non più h la espressione ufficiale de diritto, la sostanza di cui il legislatore si serve per riempir le sue formule verbali. Esiste prima della legge e al disopra del legislatore; ma, ciò nonostante, dato il principio della separazione dei poteri, il quale vieta al giudice di andare al di là della fonte formale e di verificare la sua corrispondenza con la fonte materiale, il giudice non è tanto un interprete del diritto, quato un interprete della manifestazione di volontà emanante dal legislatore; così, mentre nel sistema della formulazione giudiziaria il giudice 
legge il diritto nel texto originale, nel sistema della formulazione legislativa il giudice può leggerne soltanto la traduzione, più o meno corretta, che il legislatore ne ha fatta nelle sue leggi. Tale barriera posta tra il giudice e le vive scaturigini sociali del che sta a base di tutte le codificazioni; fidandosi sulla cosiddetta forza di espansione logica della legge, il giudice deve, con imperturbabile impassibilità, cercare una legge emanata cent'anni addietro la soluzione di tutti i problemi giuridici che un secolo di civilit'ha suscitari e che il legislatore di allora non potè neppure lontanamente prevedere. Se la legge più non risponde ai bisogni della società attuale, spetta al legislatore di oggi modificarla; ma, finchè al legislatore non ppiace di smantellre qualche torre di questo suo annoso castello, il giudice dee aggirarsi prigioneiro il mondo vive all'aperto a senza posa si rinnovella. Questa speie di segregazione legislativa ui il giudice è condannato nello Stato costituionale scito dalla Rivoluzione francese, si ripercuote anche sulla posizione che il giudice assume nel nostro ordinamento giudiziario. Se da noi il giudice non deve esere altro che un fedele interprete della volontá del legislatore, le qualità che piú si devono pregiare in lui son quelle dell'acume logico, della fredda sapienz ragionatrice, dell, agilità tecnica nel servisi di tuttii gli strumenti dell'ermeneutica per sviscerare a pieno i secreti di un testo: il giudice non deve essere (come dev'essere invece nel sistema della formulazione giudiziaria del diritto) soprattutto un giurista, che, posto dinanzi a una norma giuridica, trascuri deliberatamente ogni indagine relativa alla bontà socieale del suo contenuto,, e si fermi a indagare i soli problemi he si riferiscono al suo mecanismo formale. (CALAMANDREI, Piero. Opere Giuridiche. Volume Terzo. Napoli: Morano Editore, 1968, pp. 15-17)

75 Suponha que tenhamos decidido (por razoes da teoria jurídica ou de outra teoria política) que a prática constitucional bem exige que os juízes tenham em vista e apliquem as intenções abstratas dos constituintes, embora para isso os juízes devam fazer julgamentos de moralidade política. (...). Se minhas afirmações sobre o papel da política na interpretação jurídica são fundadas, devemos esperar descobrir opiniões claramente liberais, radicais ou conservadoras não apenas sobre o que a Constituição e as leis de nossa nação deveriam ser, mas também sobre o que são. E é isso exatamente o que encontramos. (DWORKIN, Ronald. Uma questão de Princípio. $1^{\text {a }}$ ed. São Paulo: Martins Fontes, 2001, pp. 73, 246.)

76 Ellos ofrecieron el lenguaje teórico de una confrontación política de amplias dimensiones: entre el listado de esta teoría transnacional, propia de la segunda mitad del siglo $\mathrm{XX}$, pero sólo hasta ahora incorporada en la enseñanza del derecho nacional, figuraban preeminentemente los nombres de H.L.A. HART, J. RAWLS, R. DWORKIN Y R. ALEXY. Todas estas nuevas ideas antitradicionales empezaron a circular entre grupos, pero su influencia amenazaba con quedarse en ruminaciones de las élites intelectuales. En esta cocción, por tanto, faltaba un mecanismo de transmisión que asegurara, por parte de los jueces inferiores, más apegados a la teoría tradicional, un mínimo de cooperación con los nuevos idearios teóricos y constitucionales. En efecto, la instalación en el sistemajurídico de esta nueva sensibilidad constitucional fue "parcial", en el sentido de que la Corte Constitucional debió compartir escenario con lajurisdicción común que, para todos los efectos prácticos, continuó trabajando dentro de modelos más o menos tradicionales de función judicial. Estajurisdicción común puede ser definida en bloque, por formación, como "tradicional/positivista". Ello significa, en conjunto, que en su idea de derecho se conserva una rígida dicotomía entre legislación y adjudicación, por 
"Porque la politicidad es rasgo consustancial a la misión jurisdiccional y la sentencia constituye un propio acto político y de imperio, en tanto se dicta en nombre del Estado, además de contener una decisión que escoge entre varias alternativas, lo que la erige en un acto de gobierno que, por añadidura, implica una programación del comportamiento social. Empero, naturalmente, politicidad no significa partidismo y sectorialización. Más aún, el Poder Judicial integrado por todos los jueces es, igualmente, un poder político, al menos en cuanto órgano del Estado y también por las funciones que le están asignadas". ${ }^{77}$

\section{Considerações finais}

No Brasil, um dos grandes problemas decorrentes da contraposição entre o substancialismo e as teorias processuais (procedimentalismo) reside no fato de que alguns autores, ao sobrevalorizarem o procedimento, elevando-o à condição de princípio fundante da democracia, deixam de dar a devida importância aos direitos fundamentais sociais.

Por exemplo, a chamada "judicialização da saúde", que se apresenta através de um volume crescente de ações judiciais, que via de regra resultam em tutelas antecipadas que o gestor demandado, correta ou incorretamente, se vê na contingência de cumprir. Para os que conhecem os complexos meandros do sistema de saúde, público e privado, assustam as liminares e/ou sentenças na medida em que desorganizam ou desestruturam o sistema de saúde (em construção), comprometem programas e desaceleram esforços.

Tanto a Constituição Federal quanto o próprio sistema jurídico visam tutelar o direito à vida, cabendo muita discussão quando algo a isso se refere. Entretanto, em muitos casos não é isso que está seguramente em jogo. E muitos magistrados apontam a dificuldade de encontrar fontes que propiciem um claro discernimento dos casos concretos que lhe são postos.

Há inúmeros registros de equívocos e excessos, e isto tem suscitado manifestações até de pessoas não vinculadas diretamente aos problemas. Dentre os

un lado, y entre su especialidad funcional (derecho civil, penal o laboral) y las órdenes abstractas del derecho constitucional, por otro. Su definición del derecho, además, concentrada durante años en la defensa del círculo propiedad/contrato/sucesión, los hacía poco sensibles a la tarea de definir y defender nuevos derechos no vinculados a los tradicionales. (MEDINA, Diego Eduardo López. El Derecho de los Jueces. Segunda Edición. Bogotá-México: Legis, 2006, pp. 322-323.)

77 BERIZONCE, Roberto Omar. Activismo Judicial y Participación en la Construcción de lãs Políticas Públicas. Civil Procedure Review, v.1, n.3: 46-74, sep./dec., 2010, p. 54. 
excessos, cite-se as ordens de prisão a médicos que não cumprem ordem judicial de internação de pacientes em UTI's por falta de vagas. "Quando um juiz determina a um administrador público que faça isto ou aquilo, pague isto ou aquilo, estaria ele intervindo na gestão pública e fazendo política”?

Então, se o processo é um instrumento para a efetivação da Constituição (...), entender a Constituição, também enquanto processo, significa que a ordem constitucional não é uma ordem totalmente estabelecida, mas que vai sendo criada por meio da relação entre a Constituição material e os procedimentos de interpretação e concretização de tais direitos - por exemplo, a saúde. O problema está na pretensão de autonomização das teorias processuais.

Sendo assim, por meio do Ativismo Judicial Substancialista, há de se conferir que a interpretação aplicada pelo juiz dá melhores respostas aos anseios da sociedade democrática. Por esta teoria, o juiz adotará a responsabilidade correspondente ao papel que exerce diante do modelo de Estado acima citado, valorizando este julgador uma prática interpretativa e hermenêutica.

Para Ollero, deve-se assim rever:

"el papel de la función judicial equivale a redimensionar el papel del Estado. es preciso devolverse su función de cauce racional de la actividad social; hacerle ofrecer al individuo una garantía mínima de sus derechos; apártale de toda pretensión de monopolizar lo político, porque despolitizar a la sociedad equivale a aniquilarla. Sólo reconduciendo lo político y lo social (a la superación ética de la insolidaridad) cabrá reconciliar lo público y lo privado. Cuando lo político lo monopoliza el Estado, tiende a considerar la actividad social como interés privado particularista e ilegitimo; a la vez invita a que la sociedad considere lo público como lo estatal, enfocando como una ajena prestación de servicios y asumiendo al respecto una actitud estérilmente reivindicativa. El individuo ha de entender lo público como actividad social (ni privada ni estatal), y responsabilizarse de la participación que ella le exige; el Estado ha de renunciar a monopolizar lo público (estatalizándolo) y a considerar la actividad social como un intrusismo perturbador, para aspirar a encauzarla sin disminuir su potencialidad. Reconciliar lo público y lo privado equivale a reconstruir el Estado, convirtiéndolo en instrumento de la sociedad".78

As decisões tomadas, em especial pelas Cortes Constitucionais ${ }^{79}$,têm um efeito altamente criativo/construtivo que incide através da hermenêutica e

78 OLLERO, Andres. Interpretacion del Derecho y Positivismo Legalista. Madrid: Editorial Revista de Derecho Privado, 1982, p. 165

79 Essas particularidades resultam das relações próximas da jurisdição constitucional com as funções da direção e configuração política. A jurisdição constitucional tem de decidir questões mais numerosas com toque político e de alcance político do que 
da interpretação criativa-construtiva do Direito Por derradeiro, as decisões jurídicas por tal órgão exaradas são decisões essencialmente políticas, e estas, além de apresentar criação de ex novo, regulam também os demais órgãos que compõem o Estado ${ }^{80} .{ }^{81}$ Configura-se assim uma tenaz função política, a qual

outras jurisdições. Suas próprias decisões podem desdobrar efeitos políticos de alcance considerável. Elas podem avizinhar-se de uma decisão política, tanto mais que elas regularmente podem ser obtidas não sobre a base de normalizações detalhadas, senão somente com base nos critérios amplos e indeterminados da Constituição. A realização dessas decisões, finalmente, está sujeita a condições completamente diferentes do que aquelas de outras decisões judiciais. (HESSE, Konrad. Elementos de Direito Constitucional da República Federal da Alemanha. Tradução (da 20ª Edição alemã) Luís Afonso Heck. Porto Alegre: Fabris Editor, 1998, pp. 420-421.)

80 Orbene, è proprio questo l'effetto della preposizione politica: anzi, ben può dirsi che essa rappresenti un efficace strumento per rafforzare la possibilità — di cui si è detto in precedenza- di individuare un caso concreto quale esempio di un criterio generale di condotta, senza la necessità di "ulteriori direttive". Nominare un interprete 'di fiducia' ovvero un interprete che in qualsiasi momento può essere rimosso dal suo ufficio ne condiziona l'attività ermeneutica, prevenendo il rischio che, tra più significati che possono essere conferiti ad un termine generale, ne venga scelto uno non rientrante nell'accordo interpretativo' posto dal preponente e che, all'atto di applicare la norma e di stabilire se un caso concreto vi rientri o meno, si dia rilevanza a circostanze anch'esse estranee al medesimo 'accordo'. Più precisamente, l'effetto precipuo della dipendenza politica di un interprete consiste nell'impedirgli di partecipare all'accordo interpretativo' sul quale si basano le norme che deve applicare: non solo è piuttosto improbabile che l'individuazione di "casi normali" diversi rispetto a quelli oggetto dell'accordo' del preponente, ma qualsiasi tentativo di modificarlo equivale ad un dissenso cui il preponente ben può rimediare con la rimozione del preposto stesso. $\mathrm{Si}$ badi che la dipendenza politica di un intérprete lo esclude, per così dire, dalla 'gestione' dell'accordo' attraverso cui il preponente ha inteso i termini generali e con il quale individuare i "casi familiari", ma non costituisce un criterio di individuazione degli stessi che si ponga accanto ed oltre l'accordo' stesso, soprattutto, poi, se si accarezza l'idea di risolvere definitivamente grazie ad essa i problemi di ambiguità e vaghezza del linguaggio normativo. (BISOGNI, Giovanni. Dipendenza Politica e Teoria Dell'interpretazione Giuridica. In: NARVÁEZ, José Ramón; MONTEROS, Javier Espinoza de los. (Coord.). Interpretación Jurídica: Modelos Históricos y Realidades. Instituto de Investigaciones Jurídicas. Serie Doctrina Jurídica, Núm. 601. México: Universidad Nacional Autónoma de México, 2011, p. 402.)

81 As políticas são agregativas em sua influência sobre as decisões políticas, e uma estratégia responsável para se atingir um objetivo coletivo não precisa tratar todos os indivíduos da mesma maneira. (...). Os juízes, como qualquer autoridade política, estão sujeitos à doutrina da responsabilidade política. Em sua forma mais geral, essa doutrina afirma que as autoridades políticas devem tomar somente as decisões políticas que possam justificar no âmbito de uma teoria política que também justifique as outras decisões que eles propõem a tomar. (...). As decisões judiciais são decisões políticas, pelo menos no 
passa a se decidir questões mais numerosas com toque político e de alcance político do que as demais jurisdições.

Não restam dúvidas que o substancialismo passa a ser entendido como um contraponto ao procedimentalismo; e a temática não é recente. No Brasil, ingressa em face do tardio "constitucionalismo brasileiro", reflexo das principais constituições europeias após a segunda grande guerra.

Conclui-se que, notadamente, o Poder Judiciário pode contribuir para o aumento da capacidade de incorporação do sistema político, o que garante aos excluidos uma oportunidade de concretização da ideia de justiça refletida no processo judicial. $^{82}$

O que nasce destas considerações é que um tema merece debates e estudos para que surjam claros e sólidos fundamentos com o objetivo de melhor orientar juristas e a sociedade, inclusive o Poder Judiciário em suas ações e decisões nas demandas que envolvam direitos sociais; no exemplo acima: a saúde. Portanto, qualquer um que tenha estudado a história, diria as vicissitudes, da saúde e do judiciário no Brasil, abraça de pronto a temática.

\section{Referências}

AGUIAR, Thais Florencio de. A judicialização da política ou o rearranjo da democracia liberal. Ponto-e-Vírgula, 2: 142-159, 2007, p. 150. Disponível em: <http://www.pucsp.br/ponto-e-virgula/n2/pdf/11-thais.pdf>. Acesso em: 13-07-2013.

BACHOF, Otto. Estado de Direito e Poder Político. Boletim da Faculdade de Direito de Coimbra. Vol. LVI. Coimbra: Coimbra Editora, 1996.

BADIN, Jean. Teoría General del Derecho. Madrid: Editorial Revista de Derecho Privado, 1995.

sentido mais amplo que remete à doutrina da responsabilidade política. (DWORKIN, Ronald. Levando os Direitos a sério. $1^{\text {a }}$ ed. São Paulo: Martins Fontes, 2002, pp. 137-138.)

82 Embora classificável como defensor de uma posição liberal contratualista, Dworkin se aproxima, em alguns pontos, dessa posição, entendendo que a criação jurisprudencial do direito também encontraria o seu fundamento na primazia da Constituição. Consultar CAPPELLETTI, Mauro. Juízes legisladores? Porto Alegre: Fabris, 1988; DWORKIN, Ronald. Law's empire. Cambriedge/Massachusetts: Harvard University Press, 1986; Taking rights seriously. Cambridge, Mass.: Harvard University Press, 1977; A matter of principle. Cambridge, Mass.: Harvard University Press, 1985; VIANNA et al, op. cit. In: STRECK, Lenio Luiz. Jurisdição constitucional e decisão jurídica. São Paulo: Editora Revista dos Tribunais, 2013, p. 162. 
BARROSO, Luís Roberto. Judicialização, Ativismo Judicial e Legitimidade Democrática. Disponível em: <http://www.oab.org.br/oabeditora/users/revista/

1235066670174218181901.pdf >. Acesso em: 12-06-2013.

BARROSO, Luís Roberto. Jurisdição Constitucional: A Tênue Fronteira Entre o Direito e a Política. Disponível em: < www.migalhas.com.br/arquivos/2014/2/ art20140204-06.pdf>. Acesso em: 03-09-2013.

BERIZONCE, Roberto Omar. Activismo Judicial y Participación en la Construcción de lãs Políticas Públicas. Civil Procedure Review, v.1, n. 3: 46-74, sep./dec., 2010.

BIONDI, Biondo. Arte y Ciencia del Derecho. Barcelona: Ediciones Ariel, 1953.

BISOGNI, Giovanni. Dipendenza Politica e Teoria Dell'interpretazione Giuridica. In: NARVÁEZ, José Ramón; MONTEROS, Javier Espinoza de los. (Coord.). Interpretación Jurídica: Modelos Históricos y Realidades. Instituto de Investigaciones Jurídicas. Serie Doctrina Jurídica, Núm. 601. México: Universidad Nacional Autónoma de México, 2011.

BODNAR, Zenildo; STAFFEN, Márcio Ricardo. Juizados especiais e ativismo judicial à luz de Luis Alberto Warat. In: Sequência (Florianópolis) No. 64 Florianópolis jul. 2012.

CALAMANDREI, Piero. Opere Giuridiche. Volume Terzo. Napoli: Morano Editore, 1968.

CAPPELLETTI, Mauro. Juízes Legisladores? Tradução: Carlos Alberto Álvaro de Oliveira. Porto Alegre: Sérgio Antônio Fabris Editor, 1993.

CAPPELlETTI, Mauro. Processo, Ideologia e Sociedade. Vol. 1. Porto Alegre: Sergio Antonio Frabris Editor, 2008.

CHEVALLIER. Jaçques. O Estado Pós-Moderno. Belo Horizonte: Fórum, 2009.

COTTA, Sergio. Que es el Derecho. Madrid: Rialp, 2000.

DWORKIN, Ronald. Levando os Direitos a sério. $1^{\text {a }}$ ed. São Paulo: Martins Fontes, 2002.

DWORKIN, Ronald. O Império do Direito. $1^{\text {a }}$ ed. São Paulo: Martins Fontes, 1999.

DWORKIN, Ronald. Uma questão de Princípio. $1^{\text {a }}$ ed. São Paulo: Martins Fontes, 2001.

GARAPON, Antoine. O juiz e a democracia. O guardião das promessas. Tradução: Maria Luiza de Carvalho. $2^{\mathrm{a}}$ ed. Rio de Janeiro: Revan, 2001. 
GARGARELLA, Roberto. Democracia deliberativa y el papel de los jueces frente a los derechos sociales. Disponível em: < http://new.pensamientopenal. com.ar/01102010/derechoshumanos02.pdf >. Acesso em: 06-09-2012.

HABERLE, Peter. Hermenêutica Constitucional. Tradução: Gilmar Ferreira Mendes. Porto Alegre: Fabris Editor, 1997. Reimpressão 2002.

HABERMAS, Jürgen. Direito e Democracia: entre factividade e validade. Volume I. Tradução: Flávio Beno Siebeneichler. Rio de Janeiro: Tempo Brasileiro, 1997.

HESPANHA, António Manuel. Ideias sobre a Interpretação. In: NARVÁEZ, José Ramón; MONTEROS, Javier Espinoza de los. (Coord.). Interpretación Jurídica: Modelos Históricos y Realidades. Instituto de Investigaciones Jurídicas. Serie Doctrina Jurídica, Núm. 601. México: Universidad Nacional Autónoma de México, 2011.

HESSE, Konrad. Elementos de Direito Constitucional da República Federal da Alemanha. Tradução (da 20ª Edição alemã) Luís Afonso Heck. Porto Alegre: Fabris Editor, 1998.

KELSEN, Hans. Teoria Geral do Direito e do Estado. $3^{a}$ ed. São Paulo: Martins Fontes, 2000.

LUHMANN, Niklas. El Derecho de la Sociedad. México: Universidad Iberoamericana, 2002.

MEDINA, Diego Eduardo López. El Derecho de los Jueces. Segunda Edición. Bogotá-México: Legis, 2006.

MIRANDA, Pontes de. Fundamentos Actuales do Direito Constitucional. Vol. I. Rio de Janeiro: Collecção de Cultura Social, 1932.

MONTEIRO, Cláudia Servilha. A racionalidade da decisão judicial política. In: Revista Brasileira de Estudos Políticos.

MORELLO, Augusto M. El Derecho y Nosotros. La Plata: Librería Editora Platense, 2000.

MORIN, Edgar. El Método: La Humanidad de la Humanidad. La Identidad Humana. $1^{a}$ Ed. Madrid: Catedra Teorema, 2003.

MORIN, Edgar. La Vía. Para el futuro de la humanidad. 1ª Ed. Barcelona: Paidos, 2011.

NIÑO, Carlos S. La Filosofía del Control Judicial de Constitucionalidad. In: Revista del Centro de Estudios Constitucionales. Núm. 4. Septiembre-diciembre, 1989.

OLIVEIRA, Andrade Cattoni de. (coordenação). Jurisdição e hermenêutica constitucional no Estado Democrático de Direito. Belo Horizonte: Editora Mandamentos, 2004. 
OLLERO, Andres. Interpretacion del Derecho y Positivismo Legalista. Madrid: Editorial Revista de Derecho Privado, 1982.

PASSOS, J. J. Calmon de. Direito, Poder, Justiça e Processo. Julgando os que nos Julgam. Rio de Janeiro: Forense, 1999.

PICÓ i JUNOY. El Derecho Procesal entre el Garantismo y el eficácia: Un debate mal planteado. In: AROCA, Juan Montero (Coord.). Proceso Civil e Ideología. Un prefacio, una sentencia, dos cartas y quince ensayos. Valencia: Tirant to Blanch, 2006.

PORTO, Noemia Aparecida Garcia. O Juiz no contexto da interpretação jurídica. Bimestral. Idéias Legais - Ano 1 - no 4 - Julho e agosto. Campo Grande - MS: Escola Superior da Magistratura da 24a Região, 2005.

SICHES, Luis Recásens. Nueva Filosofia de la Interpretacion del Derecho. Segunda Edicion. México:Editorial Porrúa, S.A., 1973.

SILVA, João Fernando Vieira da. O resgate da idéia de constituição dirigente no constitucionalismo pátrio. Disponível em: $<$ http://www.mundo juridico.adv. br>. Acesso em: 03-05-2013.

SILVA, Ovídio A. Batista da. Processo e Ideologia: o paradigma Racionalista. 2. Ed. Rio de Janeiro: Editora Forense, 2006.

STRECK, Lenio Luis. Verdade e Consenso. Constituição, Hermenêutica e Teorias Discursivas. 4ª Ed. São Paulo: Saraiva, 2011.

STRECK, Lenio Luiz. Jurisdição Constitucional e Hermenêutica - Uma nova crítica do direito. Porto Alegre: Livraria do Advogado, 2002.

VIANNA, Luiz Werneck; CARVALHO, Maria Alice Resende de; MELO, Manuel Palácios Cunha; BURGOS, Marcelo Baumann. A judicialização da política e das relações sociais no Brasil. Rio de Janeiro: Renavan 1997.

WARAT, Luis Alberto. Introdução Geral ao Direito III: O Direito Não Estudado Pela Teoria Jurídica Moderna. Porto Alegre: Sergio Antonio Fabris Editor, 1955. 